\title{
The social in change: property rights contradictions in Finland
}

\author{
Pekka Salmi*
}

Correspondence: pekka.salmi@rktl.fi

Finnish Game and Fisheries

Research Institute, Enonkoski,

Finland

\begin{abstract}
The concept of social sustainability is occasionally used in fisheries political argumentation, but practical policies are typically guided by ecological and economic arguments rather than the social. On the other hand, social justice and moral acceptability are general prerequisites for successful fisheries governance. This paper studies the changing social dimensions in Finnish fisheries where interactions between the water-owner-based management system and various user groups have produced enduring contradictions. Along with a shift towards recreational fishing, the national and international levels of fisheries governance have largely replaced the local owner-based management system. Consequently, increasing numbers of new interest groups, rural-urban relations, management measures and governance institutions have become part of the fisheries complex. Contradictions typically culminate in fishing rights and the power to decide over access to fishing waters. The biodiversity and wildlife conservation measures have often underrated the social, as well as economic, aspects of fishing.
\end{abstract}

\section{Introduction}

In fisheries governance, natural sciences have held a hegemonic position as the basis for knowledge. As Svein Jentoft (2006:672) holds, this situation should be 'replaced by a multi- or, ideally, inter-disciplinary approach to fisheries management, where the social and economic issues are examined as thoroughly and systematically as those of the natural systems'. This is needed because social justice and moral acceptability are general prerequisites for successful fisheries governance. The general argumentation concerning the importance of social dimensions does not, however, seem to guide practical policies.

According to David Symes and Jeremy Phillipson (2009) the policy makers are 'strangely unwilling to incorporate explicit social objectives into the design of fisheries policy'. They note that incorporation of sustainable development approaches in fisheries policy has paradoxically weakened the status of social objectives. For instance, the prioritization of 'inter-generational justice' over 'intra-generational equity' has diminished the social dimension of fisheries policy. Policy makers have been preoccupied with driving down fishing effort due to overfishing and enhancing economic efficiency in line with a neo-liberal approach to sustainable economic growth. Moreover, Symes and Phillipson (2009:4) note that 'Allied to the scarcity of relevant social data on the fishing industry is a lack of awareness of the social ethos, context and relationships of the fishing industry and the fishing community'.

(c) 2012 Salmi; licensee Springer. This is an Open Access article distributed under the terms of the Creative Commons Attribution License (http://creativecommons.org/licenses/by/2.0), which permits unrestricted use, distribution, and reproduction in any medium, provided the original work is properly cited. 
Social sustainability, like the sustainable development concept, is multi-dimensional and difficult to define (Rannikko 1999:397). A prerequisite for social sustainability is that local communities learn new practices and, at the same time, the non-local actors adapt their strategies to the circumstances of local people and nature (Jokinen 2005:47). Cultural sustainability can be seen as a sub-class of social sustainability. In cultural sustainability 'Development is in harmony with the cultural concepts of the individuals involved' (Rannikko 1999:397). The variability and context dependency of social phenomena is a challenge, if not an obstacle, when aiming to construct quantitative and comparable indicators for sustainability. Anthony Charles (2001) has provided checklists and indicators for operationalizing the practical assessment of sustainability in fisheries systems. Also Glaser and Diele (2004) list multiple criteria postulated in the social sustainability literature: quality of life, social peace, a strong civil society, participation, the degree of incidence of different forms of poverty and exclusion, distributional equity, justice and human rights, cultural identity and diversity, the maintenance of social capital and the effectiveness of social institutions and norms. The relative importance of any one social sustainability criterion is highly dependent on a region's cultural, political, social and economic context. Thus Glaser and Diele hold that social sustainability lacks the possibility of abstraction from the specific context which is characteristic of economic and biological sustainability criteria.

Social perspectives and interactions are crucial for understanding fisheries governance. Chuenpagdee et al. (2005:25-26) have noted that 'Social justice is a key issue in fisheries, since the distribution of power and income and the allocation of rights change in relation to access to resources'. Studying the location and exercise of power is important in order to understand how the governing system functions, although this is not an easy task due to the complexity and partly hidden nature of the power positions. Chuenpagdee et al. also emphasize change in governance processes. As the society and fisheries, together with the governance systems, are undergoing transformation is it feasible to use the social sustainability concept? Increasing numbers of interested parties, knowledge producers and governance institutions at different scales have become part of the dynamic fisheries complex. Thus one is entitled to ask whose interests and values should be sustained? Should we rather talk about social justice and wellbeing?

When social sustainability is defined as: 'Development reinforces the individuals' control over their own lives. The results of development are distributed equitably' (Rannikko 1999:397), the components of social justice are evident. For instance, in the case of a new fishery regulation, it is not unusual for local community members to find the fairness of the governance procedures (Engelen et al. 2008:10) unacceptable, although they could live with the consequences of the particular regulation. The broad social wellbeing framework explores relationships between environmental, social, political and economic sustainability by putting the human being at the center of the analysis (Coulthard et al. 2011:454). It focuses on the wide range of social relationships that are integral to people achieving their wellbeing. Also in this approach social justice is important: in governance the agents of change must ask whether their actions will raise wellbeing throughout the population and in a socially just fashion (Ibid:461). By studying the socio-cultural dimensions and heterogeneity in fisheries, the social wellbeing perspective helps towards an understanding of the conflict around policy regimes. The different visions and strategies for wellbeing that different people hold and pursue are often not compatible with others, which poses a challenge for governance (Ibid:459). 
This paper studies the changing social dimensions in fisheries conflicts and their management. Finnish fisheries are examined as an example of situations where, in addition to nature conservation interests, recreational use of fish resources has become topical and where a variety of resource user groups operate within the same system. In the public debates ecological perspectives are typically more vocally addressed than the social ones. On the other hand, Finnish contradictions typically culminate in debates over property rights, particularly regarding rights for fishing and the power to decide about access to fishing waters; these are essentially social-political debates. Property rights are important from the perspective of social sustainability, because they determine people's possibilities to gain wellbeing from fisheries and to participate in the governance procedures. Moreover, different stakeholder groups hold different visions and illusions about property rights, which easily lead to contradictions.

Historically, abundant inland and coastal water areas in a sparsely populated country have provided rich fishing opportunities for the Finns. Although a notable culture of fishing and fish consumption has prevailed, recent transformations and contradictions challenge the sustainability of fisheries especially from the social and economic perspectives. The major transformation in fishing activities has been a shift from commercial harvest towards recreational fishing. Parallel with this development, national and international levels of fisheries governance have partly replaced the established local ownerbased management system in Finland. Thus the governance system involves an increasing number of interest groups, rural-urban relations, management measures and governance institutions. The resulting conflicts reflect the importance - and complications - of reaching harmony on property rights.

Property rights systems are complicated as they derive from physical factors and from social and political factors. Ownership is a combination of public and private, largescale and small-scale, enduring and transient, settled and contested claims (McCay 2009:24). In some cases the essence of ownership may be formal and clear, but typically it is a mixture which reflects who is doing the definition and with what power, and how the property rights are agreed upon and configured (McCay 2009:24). The discussion benefits from dividing property rights into more precise concepts like use rights and management rights (Charles 2001:281).

Rights-based management has become a popular concept in fisheries management stressing the importance of privatized access systems such as individual transferable quotas, where marketable commodities are in private ownership. For instance in their study of property rights regimes in European inland commercial fisheries Sipponen et al. (2010) presumed that privatization of fishing rights would increase efficiency. The results showed, however, that public property right regimes accounted for higher catches and employment than the private ones.

Social relations and community membership, along with the economic perspectives, are significant forces in property rights and ownership systems. McCay (2009:20) has described the 'commons' notion of ownership, which is closely connected with community membership and the community-based transmission of knowledge. 'This kind of ownership is about knowing and belonging, about identity and long-term, meaningful relationships with natural systems' (McCay 2009:20).

This analysis is inspired by the theory of interactive governance (Kooiman 2003; Kooiman 2005). The various changes in Finnish fisheries have increased complexity and diversity of 
both the system-to-be-governed and the governing system. Conflicts constitute one form of interaction, which have shaped the governing system and the property rights regime. They reflect repeated difficulties in achieving balance between different visions and often incompatible strategies for wellbeing. The following short descriptions of various tensions and conflicts in Finnish fisheries are based on research findings and a collection of other published material.

\section{Social change and tensions in Finnish fisheries} Water owners, landless people and commercial fishing

Interactions between the water-owner management system and various user groups have produced enduring contradictions in Finnish fisheries. Starting more than one hundred years ago these tensions were manifested in the rise of the commercial fisheries, which were operated by landless people, and later in relation to recreational fishing. Most of the Finnish coastal and inland waters have traditionally been under private ownership and associated with the possession of land. This was codified in a statute of the year 1766 when Finland was a part of Sweden (Eklund 1994). In the 1902 fisheries legislation the fishing rights of the landless people - the majority of professional fishers - became weaker. The landowning farmers were allocated more decision power over fishing in their water areas. This reform was based on the idea that professional fishing should be operated by the land and water owning segment of the population (Eklund 1994).

As in other primary production sectors, employment in Finnish fisheries declined drastically during the $20^{\text {th }}$ century. In 1901 the number of commercial fishers was at least 20000 (Eklund 1991), but in 2009 only 2 398, 2077 of which operated in the Baltic Sea and 321 in the inland waters (Nylander 2010). Several factors have contributed to the decline, one being fish marketing opportunities connected to the historical changes. For instance, the Baltic fishing was developed in symbiosis with Russia for centuries, but the loss of those markets after 1917 led to a significant fall in fisheries employment (Eklund 1991). Later, the reduction of relative fish prices and increased competition have reduced both profitability and the number of fishers.

In the 1950s coastal fisheries faced a crisis, intensified by the fact that the Finnish state did not provide noteworthy support to the livelihoods of the people affected conversely to the situation in Norway or Sweden (Eklund 1993). The weak political status of Finnish commercial fishers has continued since the state has not been particularly interested in the economic problems of this relatively small occupational group, in contrast to the primary production of agriculture. For long, agricultural producers have formed a powerful political force in Finland, which has influenced the rural emphasis of the Finnish welfare state rationality; in the late $20^{\text {th }}$ century the field-working peasant became the symbol of the national ability for reconstruction and was economically supported by the state (Granberg 1999, Eklund 1993). The low political status of the fishers' occupational group does not stem only from its decreased size and from the national focus on agriculture. Following the decline of coastal fishing communities, the continuing fisher families remained separated from each other in remote coastal areas, which has hampered their organization, co-operation and weight in the governance system.

Fishers on the coast, archipelagos and lakes typically own their fishing equipment and harvest the waters close to their home with relatively small boats on a seasonal and 
family basis. In spite of the general decline in commercial fishing, fisheries are of economic, social and cultural importance for many coastal and inland locations. Fishers value the independence, freedom and life mode in their livelihood and regard the local community as their support. Many have a life-long commitment to their occupation and emphasize the non-monetary aims of work (Salmi and Salmi 1998; Salmi 2005). Instead of high incomes fishers stress the aim of earning enough income to make a living. The cultural resources, preferred life mode and commitment to the occupation have supported the continuation of commercial fishing for many, but the future of fishing as a livelihood in Finland seems uncertain especially at the coastal areas.

\section{The owner-based and top-down management systems}

In the Finnish owner-based local management of fisheries the decision maker is commonly a collective, namely a statutory shareholders' (fishery) association. It jointly represents the interests of individual owners in fishery matters (Salmi and Muje 2001). The traditional scope of operation has been the village. Most of these water owners' associations were established in the 1950s and 1960s when Finland was still mainly a rural society. The major land owners, typically farmers, have been at the core of decision making. The associations sell fishing licenses and typically use the income in stocking fish fingerlings. The mental model of this local management of lakes and coasts has been influenced by the management of fields or forests. Not all of the water owners are necessarily interested in fishing, but typically the decision makers in the fishery associations are household fishers using passive gear primarily for domestic consumption. The associations are, in principle, also obliged by law to provide fishing opportunities for rod fishers and commercial fishers. In locations where public water areas are available, commercial fishers have not been completely dependent on access to privately owned water areas.

In the late $20^{\text {th }}$ century many regarded the local owner-based management system as too protective and inefficient, partly due to the fact that there were large numbers of passive management units and management of many water areas was completely unorganized. In addition, the owned water areas had become dispersed and smaller in size due to the shift of land ownership especially into the hands of second home owners. The access rights of the landless population were deemed unsatisfactory by the proponents of increasing the number of urban recreational fishers. Substantial structural reform was undertaken by the Fisheries Act of 1982, which aimed at sustainable production by fostering rational fisheries management and efficient professional fishing. Fisheries Regions - new, partly administrative organizations - were established at the intermediate level of management system. The representatives of fishery associations remain in the majority, but representatives of recreational and commercial fishers are also involved. The grip of government was further strengthened in 1982 through the establishment of 11 fishery districts, under the Ministry of Agriculture and Forestry (Salmi and Muje 2001).

International agreements and the adoption of the Common Fisheries Policy (CFP) increased fisheries regulations and control after Finland joined the EU in 1995. Whereas in former days the framework for fishing was set by the local community, today major decisions affecting the local fisheries are made far outside the area (Stora 2003). The CFP emphasizes big professional fishing units, which compete in the market with the small-scale coastal fishers. Consequently, the diverse and heterogenic coastal fisheries 
tend to become marginalized. On the other hand, the CFP has neither strongly influenced nor restricted the commercial lake fisheries or recreational fishing.

\section{Towards post-productivism in fisheries}

Recent transitions in the utilization of rural natural resources and rural development have been described as a shift from productivism towards post-productivism. In line with Rannikko's (2008) study regarding Finnish forestry, the change towards postproductivism can be seen as a historical development where the emphasis has shifted from production to a diversity of resource utilization and protection. The forests provide important natural products, recreation, exercise and nature experience for many local people and visitors. In parallel with contributions to people's wellbeing, nature conservation is also an element of the post-productivist forests.

In spite of its abundant water areas Finland has never been able to compete with the big fishing countries in terms of commercial landings. Yet the productivist fisheries paradigms and ideas have prevailed for a long time, although at present it is the recreational motivations that characterize fisheries use in most water areas. As the result of an increase during the last decades, Finland is one of the leading recreational fishing countries (Varjopuro and Salmi 2003); about 35-40\% of the population fish at least once a year during their leisure time (Toivonen 2008). In 2010, there were 1.7 million recreational fishers and fishing was the most, or almost the most, important hobby for 50000 fishers (FGFRI 2011).

Finland was urbanized comparatively late but rapidly. In 1950 most of the population still lived in the countryside, but from 1970 the majority of Finns inhabited urban regions. Most people still had their roots in rural areas and enjoyed more leisure time. Summer houses, mainly built on the lake or coastal shoreline, became very popular. These cottages are also important places for sustaining and reconstructing recreational fishing activities (Salmi et al. 2006). As the summer cottage dwellers are typically urban people with their roots in the countryside, they partly follow the customs and habits associated with the past, but also give them new meanings, filtered through the modern urban perspective (Jokinen 2002). Thus the fishing culture has become partly nonlocalized (Lappalainen 1998) and the fisher groups have increased in number and variation of behavior and values (Salmi et al. 2008).

\section{Debates over fishing rights}

Along with the societal change and differentiation, social and cultural dimensions are increasingly topical issues in the governance of fisheries. As the following case studies will reveal, fisheries contradictions often culminate in property rights issues, because they determine people's practical opportunities to gain wellbeing from fisheries and to participate in governance procedures. Property rights conflicts in Finnish fisheries highlight the complexities in achieving acceptable procedures for decision making and in striking a balance between the wellbeing outcomes of divergent interests and values like those of commercial and recreational fishers and water owners.

\section{Commercial lake fisheries}

In the Finnish lake areas tensions between commercial fishing and local water owner associations have mostly concerned the fishing rights of commercial fishing for vendace with small pair trawls and seine netting (Salmi and Auvinen 1998). Conflicts occurred especially in the early 1990s when the vendace stocks were declining. The water owners' associations refused to grant permits for commercial fishing. The local owner-fishers, who used mostly 
gill nets, regarded commercial fishing practices as unsustainable for the reproduction of vendace stocks. When dealing with these conflicts in the court, fisheries scientists have generally argued that commercial fishing does not endanger the future of vendace stocks.

In the lake fisheries disputes the water owners stressed that the owners' right to make decisions about their water area without outside interference is fundamental (Salmi and Auvinen 1998). In the Lake Onkamo conflict the water owners also underlined the inequality among the fisher groups: they suggested that there are 600 gill net fishers and only two seine net teams using the fish resources of the lake. Winter seine net fishing on the ice is a traditional commercial fishing method (Figure 1). The local owner-fishers

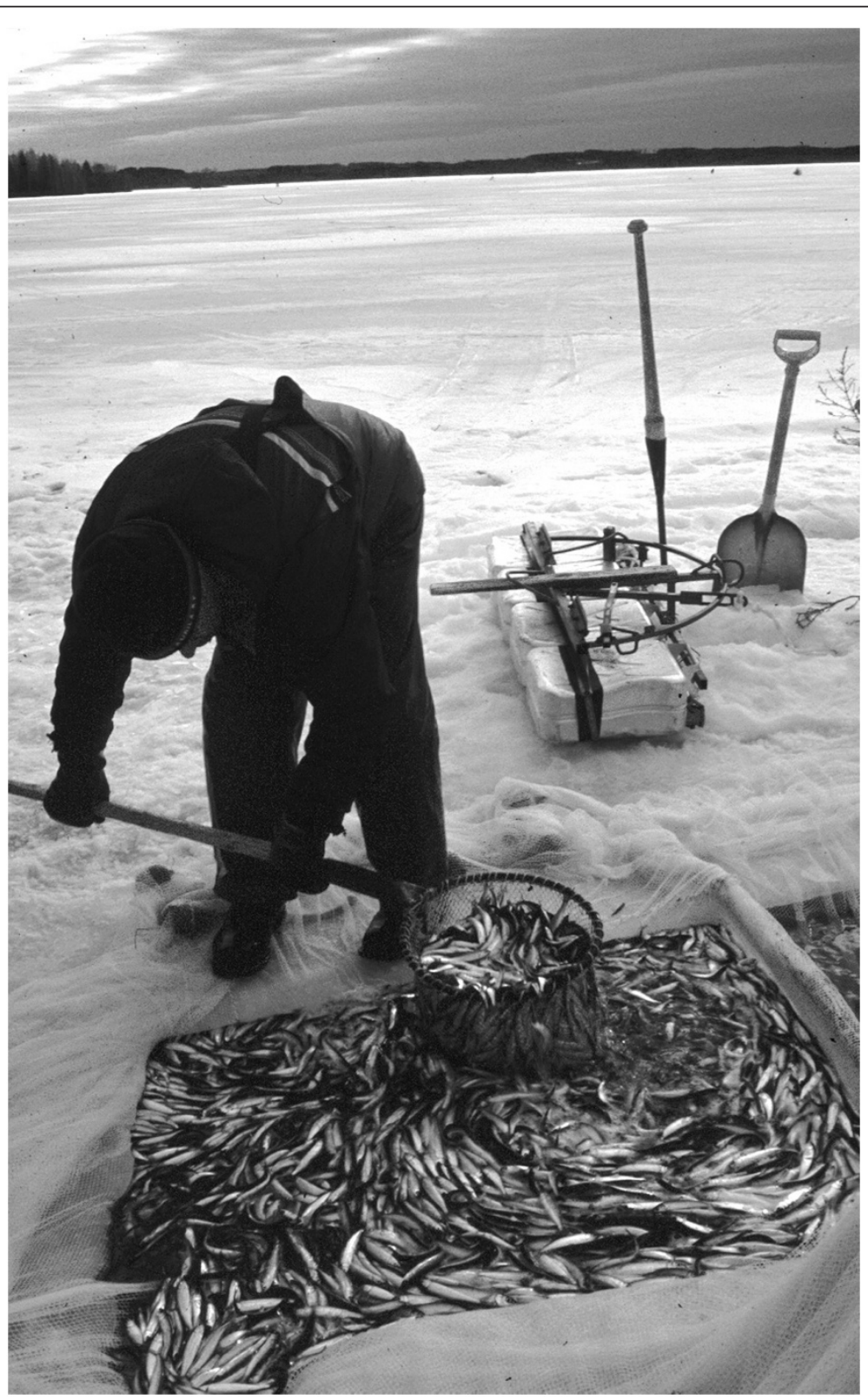

Figure 1 The most important target species of the Finnish lake fisheries, vendace (Coregonus albula), is here captured by winter seine netting. Vendace is a species of freshwater whitefish. 
prioritized the access rights of recreational gill net fishers. According to commercial fishers, the motive for reducing the seine net fishing effort derived from envy among the people of the village of their considerable income from fishing. Fisheries legislation stressed that local water owners should allow commercial fishing operations when fish stocks are not endangered. A knowledge-related problem was that owner-fishers' knowledge about the state of the vendace stocks was mediated through gill net fishing, which may cause bias due to its selectivity.

In many lake and coastal areas the water owners' associations have been positive towards the access rights of both commercial and recreational fishers. The main focus, however, has been on the needs of those who own the waters, where their activities have been supported by a strong network of fishery advisors. Typically, the most concrete activities undertaken by the central association and regional advisors in rural advisory centers have been the stocking of fingerlings. This fish stock enhancement can be interpreted as one of the main benefits of water ownership and is aimed at improving the target species of the owner-fishers. In certain, mainly Swedish-speaking coastal areas water ownership has been considered primarily as supporter of the commercial fishing culture, and in these areas there has been strong resistance to the granting of new access rights for rod fishers.

\section{Rod fishing rights}

Several rights for non-water-owners have been protected by law in Finland. For example, ice fishing with a rod and angling with a rod and natural bait are allowed irrespective of the ownership of the water (so-called 'every man's rights'). The latest change enhancing the fishing opportunities of non-owners was the adoption of a provincial lure fishing fee in 1997 (Figure 2), after a lively debate in Parliament and the media. Water owners opposed this new legislation and interpreted it as interference with private ownership and local decision making. In a series of paid announcements published in a widely circulated newspaper, the owners even argued that the state was socializing private property (Pirhonen and Salmi 1998).

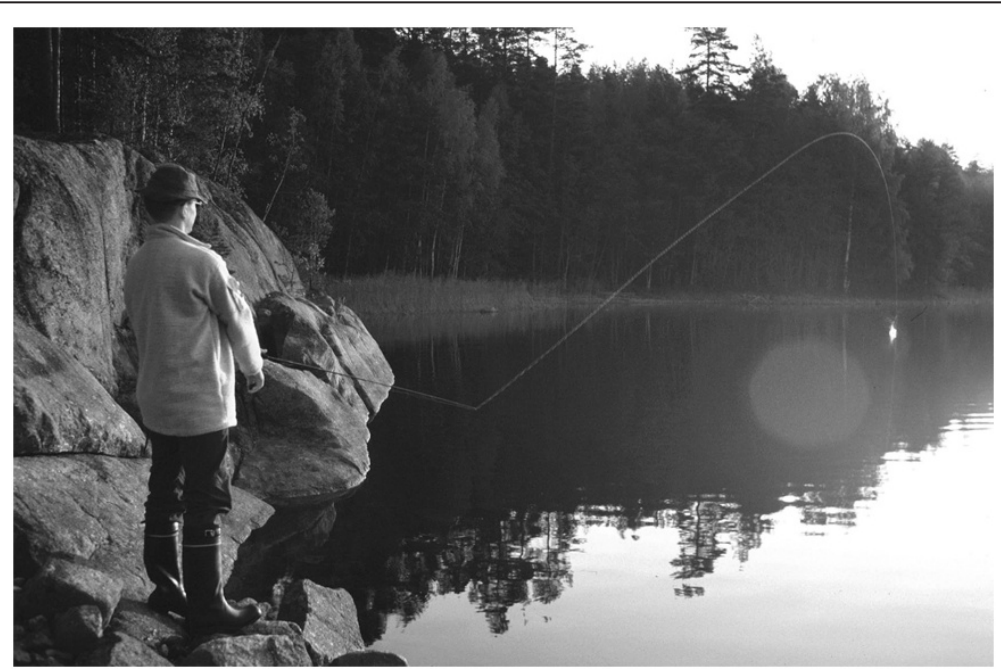

Figure 2 Since 1997 Finnish recreational fishers who use spinning rods have had access to wide-ranging water areas by paying the provincial lure fishing fee to the state. 
The resistance to the recreational fishers' relatively free access to private waters was justified by various arguments, which can be divided into three main categories: 1) the licensing system causes harm to commercial fishing and the tourist industry, 2) lure fishermen disturb nature, fish reproduction and people using the shore and 3) the licensing system hampers local management and control of fisheries (Salmi 2009a). According to the local water owners, commercial gill net fishers found spoon-baits in their nets and lures had also broken the nets. It was not so much a question of economic loss, but an addition to the diversity of problems in commercial fisheries. The situation where a highly valued livelihood is being disturbed by recreationalists from outside the area was considered unbearable. It was intimated that commercial fishing was taking second place to leisure fishermen, who do not know how to behave in the archipelago area (Salmi 2009a). The water owners found it difficult to control fishing, because they were no longer the exclusive license providers in their waters. Motivation for looking after fish stocks and supervising the compliance with fishing regulations weakened.

People in the Swedish-speaking archipelago are particularly forceful defenders of the institution of private ownership (see Taxell 1989:56). Application of the state-organized provincial lure fishing fee system reflects a long-rooted property right conflict. Already in the early 1970s commercial fishers were worried about the shift of control from the water owners and commercial fishers to those promoting recreational interests (Bergman and Österholm 1975:172). The discussion concerning the fishery management rights of local people also has features parallel to the heated debates on nature conservation and private ownership of land and water. In the case of the lure fishing fee, the strong rhetoric in favor of private water ownership reflects the need to keep the management rights in the hands of the local people - ownership can be regarded as a symbol of the community's self-determination (Salmi and Varjopuro 2001).

\section{Reforming the Finnish fisheries legislation}

Ongoing discussion over a wide ranging reform concerning fisheries legislation reveals complex issues, tensions and a variety of seemingly irreconcilable viewpoints, largely rooted in self-interest. The province-wide lure fishing fee system has been discussed in the context of guided fishing. When a fishing guide takes his clients fishing into a privately owned area, is the province-wide lure fishing fee adequate or should the fishers also obtain a permit from the local water owners? The Supreme Court of Finland has decided that the lure fishing fee granted by the state is not applicable in this type of fishing tourism business. This interpretation has made the fishing guide entrepreneurs angry and they have demanded a change in legislation. They claim that the Swedish People's Party, which represents the Swedish-speaking Finns, is the main opponent of fishing tourism (Paataja 2008). Supporters of guided fishing hold that the Swedish People's Party has been against every step towards widening the public fishing rights of recreational fishers starting with ice fishing and angling. The Secretary of State (Johansson 2008) commented that the access of guided fishing tourists to privately owned waters has always required water owners' permission. A possible change in the Fisheries Act should be made in the order of procedure required for the enactment of constitutional legislation.

In the context of the reform of fisheries legislation the spokesman of the Finnish Federation for Recreational Fishing has interpreted the social dimension of sustainability: 
"According to social sustainability legislation should secure equitable and sufficient fishing opportunities for all citizens and steer fishing in the way which can be widely accepted also by those Finns who do not fish" (Mäkelä 2008). In contrast, the Finnish Commercial Fishers' Federation (2008) has commented that scarcity of sufficient fishing water areas has hampered the fishing livelihood in many regions and legislation should be changed in order to secure sufficient fishing rights for commercial fishing. On the other hand, the Advisory board of water owners (2008) has argued that the reform of fisheries legislation should not endanger the water owners' rights to decide how fishing activities and the conservation of fish resources are arranged.

\section{Fisheries and environmentalisation}

The modern emphasis on ecological and environmental dimensions of sustainability has increasingly influenced the images of fisheries governance problems, the system-to-begoverned and the governing system. The environmentalization process in fisheries increases the complexity of the governance problems and calls for collaboration across sectoral borders (Salmi 2009b). Within the Finnish fisheries system, the state-organized regulation of Baltic salmon has given rise to deeply entrenched debates. Since the 1980s Finnish commercial salmon fisheries have been strictly regulated, primarily by closed seasons (Salmi and Salmi 2005). The regulations are based on protecting the declining wild stocks, but have also been motivated by the desire to secure catches for the recreational river fishery. This has aroused conflicts between the commercial coastal salmon fishers who harvest in the Baltic Sea and the people living in riverside Tornionjoki. The conflict is connected to perceived inequality between river stakeholders and sea fishers in the allocation of rights and opportunities for salmon fishing. The geographical distances, different motivations for fishing, regional cultures and divergent knowledge bases are elements that have made the governance of salmon fishery challenging (Salmi and Salmi 2005).

The seal-fisheries and cormorant-fisheries conflicts reflect multiple tensions between demands for rural social and economic sustainability and wildlife conservation (Salmi 2009b). The bases for these conflicts concern the damage induced by the seals and cormorants to the fishing livelihood. Grey seals are commonly regarded as the main threat in Finnish coastal fisheries and the effects of the rapidly increasing cormorant populations on fish stocks and fisheries are also hotly debated. The perspectives concerning Finnish seal politics have become divided between the fisheries and hunting groups on one hand and nature protectors and environmental administrators on the other. Similar tensions are present also in the cormorant conflict, where environmental perspectives exert greater influence, largely because the cormorant belongs to the list of species whose protection falls within the responsibility of the environmental administration.

Fisheries governance has traditionally been a multifaceted task due to the complex interactions between the social, economic, technical, and natural spheres, but the wildlife-related conflicts add a new diversity of interests, values, and knowledge. In the sealfisheries and cormorant-fisheries disputes, the governance system has increased in complexity due to the institutionalised sectoral barriers between two ministries supported by their separate research institutes (Salmi 2009b).

Recently a debate between local gill net fishing rights in the Saimaa lake area, Eastern Finland, and the conservation of the Saimaa ringed seal has gained prominence in the Finnish media. Saimaa ringed seal is an endangered species living only in this lake 
system. Compared to other threats to the seal population, like climate change, drowning of pups and adult seals in fishing gear has been the most debated one. Fishing has been regulated by the Ministry of Agriculture and Forestry in order to protect the seal since 1999. These top-down measures caused local resistance and conflicts (Tonder 2005). New pressures for the regulation of gill net fishing arose in 2006 and 2007 along with declining trend in the ringed seal population.

In 2008 a working group, where interest groups like water owners and the seal conservationists were represented, agreed on a strategy which combined fishing gear restrictions over a wide area and the targeting of increasing voluntary regulation by the local shareholders associations in terms of closed seasons. Later, a fishing gear development project was initiated (Figure 3). The voluntary regulation was realized by local shareholders associations who signed agreements for total closure of spring-time gill net fishing in the main distribution area of the seal species. This strategy was, however, soon contested by the nature protection lobby, which provoked an extensive media campaign in 2009. The resulting inflamed debates reflect a rural-urban conflict where all parties agree on the need for protection of the ringed seal, but disagree with governance procedures and practical management instruments. The local water owners and gill net fishers in Eastern Finland have been irritated by the newspaper articles that do not show respect for the willingness and ability to deal with the issue at the local and regional level. A top-down approach for banning gill net fishing instead of negotiations in the lake areas has been repeatedly suggested and nature conservationists have also appealed to the European Commission for support over seal protection.

\section{Conclusions}

This paper has focused on the changing social settings and confrontations in the fisheries system. In spite of the strengthened emphasis on ecological and economic sustainability in fisheries policy, the social and cultural dimensions are constantly critical for

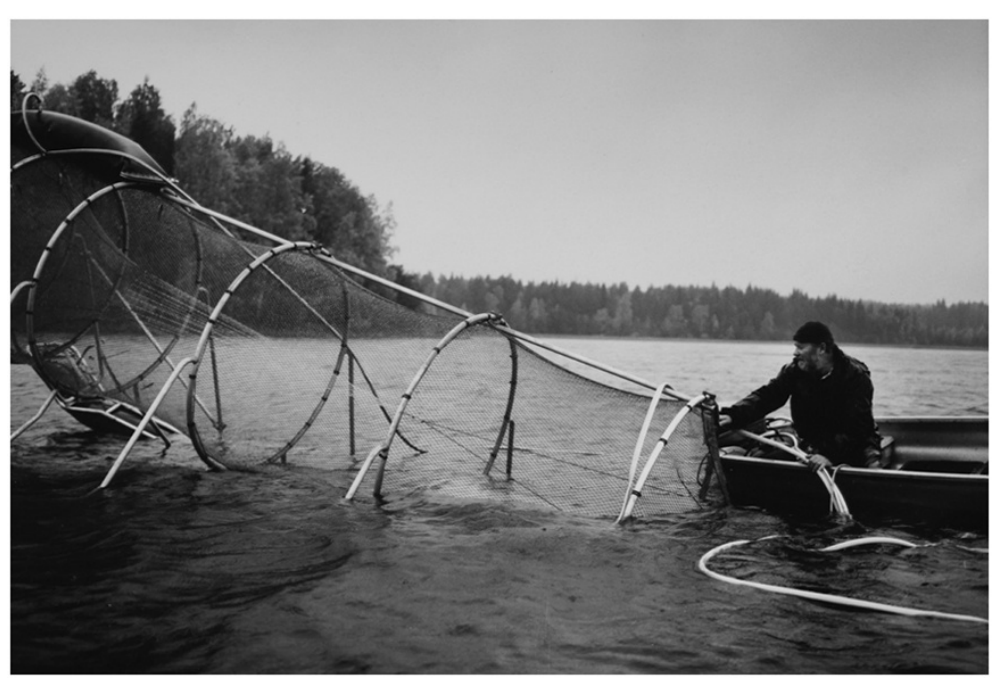

Figure 3 An EU-funded project has developed new trap net designs for the commercial fishers in the Saimaa lake area. The aim is to produce a gear which is both safe for the Saimaa ringed seals and efficient from the fishers' perspective. 
the governance of fisheries. Conflicts rise time and again as new stakeholder groups challenge the social wellbeing of the more established groups as illustrated in the context of Finnish fisheries. A connecting thread linking the reviewed fisheries debates is that they typically culminate in property rights issues and demands for social justice. Consequently, ownership, management opportunities and use rights are significant mechanisms in achieving social justice and social sustainability. When highlighting the social and political nature of property rights allocation, the findings at the same time challenge the common economic images of privatized access systems.

The historical and cultural basis of the contradictions cannot be overemphasized. Due to the transformations in fisheries and in Finnish society, including processes of postproductivism and environmentalisation, both the systems-to-be-governed and the governing systems increase in complexity and diversity, and often the interest groups become differentiated. A pertinent dividing line between the water owners and the nonowner-users of the fish resources has been embedded in the Finnish fisheries governance system. For instance, the power play between water owners and recreational fishers has led to a complicated multi-level fishing licensing system, which many fishers find hard to understand. While water owners appealed to the constitutional rights of private ownership, recreational fishers used their political power in order to change legislation in the favor of their fishing opportunities. Rather than marketable commodities, at the local level, property rights and ownership symbolize community selfdetermination, and also serve as an instrument of resistance to outside interference and change. This explains the social and cultural importance of ownership.

The context-dependency of social phenomenon can be detected in the relationships between Finnish water owners and commercial fisheries, which ranged from contradictory to symbiotic. In the past commercial fisheries were marginalized in relation to agriculture, but later the recreational and environmental values have become increasingly vocal in comparison to fishing and other rural livelihoods. Although commercial and recreational fisheries operate in the same governance framework and use the same fish resources, the moral discussion about the access rights between a small number of professionals and a large number of hobbyists has been muted.

In the change towards post-productivist fisheries systems, the multiplicity of user groups and interests amplifies the need to strike a better balance between ecological, economic and social dimensions of sustainability. In political debates on fisheries the social arguments are often hidden behind ecological and economic rhetoric, although many of the debates deal with social dimensions like moral acceptability and social justice. In the absence of thorough discussion the age-old positions are easily sustained. Multi- and interdisciplinary studies on social wellbeing - initiated or supported by the fisheries system - could help in finding common ground.

Commercial fisheries have often been squeezed into narrow operational space, mostly due to fishing restrictions. Conservation-driven approaches to governance are typically in favor of science-based, hierarchical modes, which lack stakeholder participation and inclusion of local knowledge. This risks the successful mitigation of the conflicts, because local groups put great emphasis on the fairness of governance procedures. Searching for new co-governance arrangements, like partnerships between water owners and seal protectors in the Finnish case, is in line with the idea of social sustainability: local communities and water owners can learn new practices and accept the involvement of 
wider interests in local management. In the governance of multi-stakeholder fisheries special attention should be given to the processes of defining ownership and property rights: and how to strike a balance between the divergent interests and values in the changing society. The design of practical access rights and management rights are of vital importance in preventing or mitigating contradictions and in sustaining the wellbeing derived from fisheries.

\section{Competing interests}

The author declares that he has no competing interests.

\section{Acknowledgements}

This paper draws on earlier work of the author and on two presentations, which took place in Sustainable Fishing Communities working group of the European Society for Rural Sociology congress in Finland (2009) and in Stakeholder Knowledge panel session of the People and the Sea conference in the Netherlands (2011). The author is grateful for the fruitful discussions and comments on the paper and is also indebted to two anonymous referees and Dr. Juha Hiedanpää for supporting the development of the manuscript.

\section{Authors' contributions}

PS has written and is responsible for the whole article and has approved the final manuscript.

Received: 24 April 2012 Accepted: 6 June 2012 Published: 6 June 2012

\section{References}

Advisory board of water owners. 2008 Vesienomistajien neuvottelukunnan lausunto kalastuslain kokonaisuudistuksesta. (Comment concerning the reform of fisheries legislation.) [In Finnish.] Available: http://www.hare.vn.fi/upload/ Asiakirjat/14258/123898_vesienomistajien_neuvotteluk.pdf.

Bergman, K., and H. Österholm. 1975. Fiskets utvecklingsmöjligheter, In: Skärgård i omvandling. Miljö och människa I Finlands skärgård. Nordeskiöld-samfundet, 165-172. Borgå: [In Swedish].

Charles, A. 2001. Sustainable Fishery Systems, Fish and Aquatic Resources Series 5. Oxford: Blackwell Science.

Chuenpagdee, R., et al. 2005. Challenges and concerns in capture fisheries and aquaculture. In Fish for life. Interactive governance for fisheries. MARE Publication Series No 3:25-37, ed. J. Kooiman, M. Bavinck, S. Jentoft, and R. Pullin.: Amsterdam University Press.

Coulthard, S., D. Johnson, and J.A. McGregor. 2011. Poverty, sustainability and human wellbeing: A social wellbeing approach to the global fisheries crisis. Global Environmental Change 21: 453-463.

Eklund, E. 1991. Kustfiskets historia i Finland. Skärgård 2: 5-15 [In Swedish.]

1993. När statsmakten inte ställer upp: om sambandet mellan fiskarkärens svaga yrkesorganisering och ekonomisk-politiska marginalisering i Finland under 1900-talet. In: Fiskerisamfund - hvilke veje? - en antologi 27, 85-98. Nordisk Ministerråd: Nord 27 [In Swedish.].

1994. Kustfiskare och kustfiske i Finland under den industriella epoken. Studier i en yrkesgrupps yttre villkor, sociala skiktning och organisation 1860-1970. Svenska social- och kommunalhögskolan vid Helsingfors universitet. Forskningsinstitutet: SSKH Skrifter 5 [In Swedish.].

Engelen, E., J. Keulartz, and G. Leistra. 2008. European Nature Conservation Policy Making. From Substantive to Procedural Sources of Legitimacy. In Legitimacy in European Nature Conservation Policy. Case Studies in Multilevel Governance. Pp 3-21. The International Library of Environmental, Agricultural and Food Ethics, vol. 14, ed. J. Keulartz and G. Leistra.: Springer.

FGFRI 2011. Recreational Fishing 2010. Official Statistics of Finland, Agriculture, Forestry and Fishery. Finnish Game and Fisheries Research Institute. Riista- ja kalatalous: Tilastoja 7/2011.

Finnish commercial fishers' federation. 2008. Lausunto - kalastuslain kokonaisuudistus. (Comment concerning the reform of fisheries legis/ation.).. [In Finnish.] Available: http://www.hare.vn.fi/upload/Asiakirjat/14258/121793_sakl.pdf.

Glaser, M., and K. Diele. 2004. Asymmetric outcomes: assessing central aspects of the biological, economic and social sustainability of a mangrove crab fishery, Ucides cordatus (Ocypodidae), in North Brazil. Ecological Economics 49: 361-373.

Granberg, L. 1999. The emergence of welfare state rationality in Finnish agricultural policy. Sociologia Ruralis 39: 311-327.

Jentoft, S. 2006. Beyond fisheries management: The Phronetic dimension. Marine Policy 30: 671-680.

Johansson, S. 2008. Perustuslaki asettaa viehekalastukselle rajat. Kalastuslehti: 60-61 [In Finnish.].

Jokinen, A. 2002. Free-time habitation and layers of ecological history at a southern Finnish lake. Landscape and Urban Planning 61: 99-112.

Jokinen, P. 2005. Sosiaalinen kestävyys ja ympäristöpolitiikka maaseudun kehityksessä. Maaseudun uusi aika: 46-52 [In Finnish.].

Kooiman, J. 2003. Governing as Governance. London: Sage Publications.

Kooiman, J. (ed.). 2005. Fish for life. Interactive governance for fisheries. MARE Publication Series No. 3.: Amsterdam University Press.

Lappalainen, A. 1998. Kalastuskulttuuri muuttuvassa yhteiskunnassa. Etnologinen analyysi kalastuskulttuurin muuttumisesta Pohjois-Karjalan Höytiäisellä 1890-luvulta 1990-luvulle. Fishing culture in a changing society. Changes in fishing culture on Lake Höytiäinen from the end of the 19th century to the 1990s. [In Finnish with English summary.]: Kalastusmuseoyhdistys r.y. Julkaisuja 13.

McCay, B.J. 2009. The Littoral and the Liminal: Challenges to the Management of the Coastal and Marine Commons. MAST 7: 7-30.

Mäkelä, I. 2008. Kestävä käyttö ja kalastuslain uudistus. Vapaa-ajan kalastaja 4/2008: 2 [In Finnish.]. 
Nylander, E. (ed.). 2010. Finnish Fisheries Statistics. Kopijyvä, Kuopio: Finnish Game and Fisheries Research Institute. Available: http://www.rktl.fi/www/uploads/pdf/uudet\%20julkaisut/kalatalous_tilastoina_2010.pdf.

Paataja, A. 2008. Ruotsalainen kansanpuolue saariston elinvoimaisuuden esteenä. Kalastuslehti: 50-51 [In Finnish.].

Pirhonen, M., and P. Salmi. 1998. Viehekorttikiistan argumentit. Kamppailu kalavesien käyttö- ja omistusoikeudesta, Kala- ja riistaraportteja nro 129: Finnish Game and Fisheries Research Institute [ln Finnish.].

Rannikko, P. 1999. Combining Social and Ecological Sustainability in the Nordic Forest Periphery. Sociologia Ruralis 39:394-410

2008. Postproduktivismi metsässä. In: Ympäristösosiologian virrat ja verkostot. (Flows and Networks of Environmental Sociology.) Pp 83-95. Ed. T. Karjalainen, P. Luoma, and K. Reinikainen. University of Oulu. [In Finnish.].

Salmi, J., and P. Salmi. 1998. Livelihood and way of life: Finnish commercial fisheries in the Baltic Sea. In Northern Waters: Management Issues and Practice, ed. D. Symes, 175-183. Blackwell Science: Fishing News Books.

2005. Governance of the Baltic Salmon Fishery - Fishers' views. Paper CM 2005 N:29 in proceedings of ICES 2005 Annual Science Conference, Aberdeen, Scotland, 20-24 September. CM. 2005. Documents. CD: ASC Edition.

Salmi, P. 2005. Rural Pluriactivity as a Coping Strategy in Small-Scale Fisheries. Sociologia Ruralis 45: 22-36.

2009a. Rural-urban relations in livelihoods, governance and use of natural resources - Considerations of fisheries in the Finnish Archipelago Sea Region. In Beyond the rural-urban divide: Cross-continental perspectives on the differentiated countryside and its regulation. Research in rural sociology and development vol. 14, ed. K. Andersson, E. Eklund, M. Lehtola, and P. Salmi, 171-189. Emerald, United Kingdom.

2009b. Rural resource use and environmentalisation: governance challenges in Finnish coastal fisheries. Maaseudun uusi aika. Finnish Journal of Rural Research and Policy, Special Issue 17: 47-59.

Salmi, P., and H. Auvinen. 1998. Local conflicts in Finnish lake fisheries. In Recreational Fisheries. Social, Economic and Management aspects. Fishing News Books, ed. P. Hickley and H. Tompkins, 116-128. Oxford: Blackwell Science.

Salmi, P., and K. Muje. 2001. Local owner-based management of Finnish lake fisheries: social dimensions and power relations. Fisheries Management and Ecology 8: 435-442.

Salmi, P., and R. Varjopuro. 2001. Private water ownership and fisheries governance in Finland, Proceedings of the IIFET 2000 Conference, July 10-13, 2000: conference CD.

Salmi, P., A. Toivonen, and J. Mikkola. 2006. Impact of summer cottage residence on recreational fishing participation in Finland. Fisheries Management and Ecology 13: 275-283.

Salmi, P., E. Neuman, and T. Hakaste. 2008. Scale and participation in recreational fisheries management. Nordic examples. In Global challenges in recreational fisheries, ed. Ø. Aas, 130-149. Oxford: Blackwell Publishing.

Sipponen, M., M. Mitchell, and J. Vanberg. 2010. Does a property rights regime affect the outcome of European inland commercial fisheries? Knowledge and Management of Aquatic Ecosystems 399: 06.

Storå, N. 2003. Fiskets Åland och fiskarkulturen. Skrifter utgivna av Ålands Kulturstiftelse XVI. Mariehamn: [In Swedish with English summary.].

Symes, D., and J. Phillipson. 2009. Whatever became of social objectives in fisheries policy? Fisheries Research 95: 1-5.

Taxell, C. 1989. Samhällsutvecklingen och skärgården. Kontakt och konflikt i Skärgården, Nordenskiöld-samfundets tidskrift 49: $52-57$ [In Swedish.].

Toivonen, A. 2008. Recreational fishing in Finland. In Global challenges in recreational fisheries, ed. Ø. Aas, 21-25. Oxford: Blackwell Publishing.

Tonder, M. 2005. Anatomy of an Environmental Conflict - A Case Study of the Conservation of the Saimaa Ringed Seal. University of Joensuu: Publications in Social Sciences n:o 75.

Varjopuro, R., and P. Salmi. 2003. Co-management and recreational fishing. In: D. Wilson, J. Raakjaer Nielsen and P. Degnbol (Eds), The Fisheries Co-management Experience. Accomplishments, Challenges and Prospects. Kluwer Academic Publishers. Fish and Fisheries Series 26: 231-245.

doi:10.1186/2212-9790-11-2

Cite this article as: Salmi: The social in change: property rights contradictions in Finland. Maritime Studies 2012 11:2

\section{Submit your manuscript to a SpringerOpen ${ }^{\circ}$ journal and benefit from:}

- Convenient online submission

- Rigorous peer review

- Immediate publication on acceptance

- Open access: articles freely available online

- High visibility within the field

Retaining the copyright to your article

Submit your next manuscript at $\boldsymbol{\Delta}$ springeropen.com 